\title{
Integrative literature review: access to primary healthcare services
}

\author{
Acesso aos serviços da Atenção Primária em Saúde: revisão integrativa da literatura
}

Acceso a los servicios de la Atención Primaria de Salud: revisión integradora de la literature

\author{
Maura Cristiane e Silva Figueira', Wellington Pereira da Silva', Eliete Maria Silva' \\ 'Universidade Estadual de Campinas, Nursing School. Campinas, São Paulo, Brazil.
}

\begin{abstract}
How to cite this article:
Figueira MCS, Silva WP, Silva EM. Integrative literature review: access to primary healthcare services.

Rev Bras Enferm [Internet]. 2018;71(3):1178-88. DOI: http://dx.doi.org/10.1590/0034-7167-2017-0441
\end{abstract}

\section{Submission: 05-12-2017 Approval: 10-09-2017}

\begin{abstract}
Objective: Analyze the scientific production that describes the type of access to primary healthcare services and identify specific populations that have differentiated access to health services. Method: An integrative review. For study selection, the following databases were used: PubMed, Scopus, Bireme, and Cinahl. The sample included 22 national and international articles. Results: The results describe the access of specific populations to health services, the access to primary care through health plans and proposed improvements to the access to primary care. Conclusion: The access to services is a challenge in many countries and some strategies and policies are implemented to solve and improve primary health care.
\end{abstract}

Descriptors: Access to Tealth Services; Primary Health Care; Health Systems; Health Policies; Rural Communities.

\section{RESUMO}

Objetivo: analisar a produção científica que descreve a forma de acesso aos serviços da Atenção Primária em Saúde e identificar as populações específicas que têm acesso diferenciado aos serviços de saúde. Método: revisão integrativa. Para a seleção dos estudos, utilizou-se as bases de dados: PubMed, Scopus, Bireme e Cinahl. A amostra incluiu 22 artigos nacionais e internacionais. Resultados: descrever sobre o acesso de populações específicas aos serviços em saúde, acesso a cuidados primários por meio de planos de saúde e algumas proposições para melhorar o acesso. Conclusão: o acesso aos serviços é um desafio em muitos países e algumas estratégias e políticas são implementadas para a resolução e melhoria do cuidado na atenção primária.

Descritores: Acesso aos Serviços de Saúde; Atenção Primária em Saúde; Sistemas de Saúde; Política de Saúde; Comunidades Rurais.

\section{RESUMEN}

Objetivo: analizar la producción científica que describe la forma de acceso a los servicios de la Atención Primaria de Salud e identificar las poblaciones específicas que tienen acceso diferenciado a los servicios de salud. Método: revisión integradora. Para seleccionar los estudios, se utilizaron las bases de datos: PubMed, Scopus, Bireme y Cinahl. La muestra incluyó 22 artículos nacionales e internacionales. Resultados: describir sobre el acceso de poblaciones específicas a los servicios de salud, acceso a cuidados primarios por medio de seguros médicos y algunas propuestas para mejorar el acceso. Conclusión: el acceso a los servicios es un reto en muchos países y algunas estrategias y políticas son aplicadas para la resolución y perfeccionamiento del cuidado en la atención primaria.

Descriptores: Acceso a los Servicios de Salud; Atención Primaria en Salud; Sistemas de Salud; Política de Salud; Comunidades Rurales. 


\section{INTRODUCTION}

In most countries, primary care is essential and reorganizes health systems, providing the possibility of better care to individuals; it is based on methods and technologies that should be near the population, their jobs and their families, it is the first contact with health care ${ }^{(1)}$. Studies have shown that difficult accessibility to primary care services is not only related to the geographical aspect, but also to the lack of services that take into account organizational, economic, social, cultural, religious, epidemiological and communication aspects with the team ${ }^{(2-4)}$.

Access is an important factor in explaining variations in the use and supply of health services to population groups and represents a relevant dimension in studies that analyze equity in health systems ${ }^{(5)}$. Some specific population groups remain in vulnerable and deficient situation in terms of access to and inclusion in health programs, such as immigrants, quilombolas, settlers and indigenous populations. For this reason, although access and accessibility are often used as synonyms, they have different or complementary meanings. Accessibility refers to the characteristics of the service offer that enable people to access services, while access is the way people perceive accessibility ${ }^{(4)}$.

Therefore, ensuring access and accessibility to quality services is one of the most important responsibilities of global public health systems, with a view to enabling attention to acute and chronic health problems and articulating actions of health promotion and disease prevention and treatment ${ }^{(6)}$.

In all the countries where it is present, the organization of primary health care and the provision of services are regulated by several legislative acts created and managed to provide access, full care, longitudinality, and cost minimization in the sector ${ }^{(7)}$.

To systematize the knowledge on this theme, we conducted bibliographical reviews of national and international databases, in search of aspects and/or initiatives related to the access of patients and specific populations to primary healthcare services, based on the following guiding questions: What is the access to health services like in different countries? Do specific populations have differentiated access?

For this review, a project was designed for the Institutional Program for Scientific Initiation Scholarships (PIBIC - Programa Institucional de Bolsas de Iniciação Científica) in the Nursing program of the State University of Campinas (Unicamp - Universidade Estadual de Campinas), funded by the National Council for Scientific and Technological Development (CNPq - Conselho Nacional de Desenvolvimento Científico e Tecnológico), linked with doctoral research developed with the Study and Research Group for Nursing and Health Education and Practices (GEPEPES - Grupo de Estudos e Pesquisas em Educação e Práticas de Enfermagem e Saúde).

\section{OBJECTIVE}

To analyze the scientific production that describes the type of access to primary healthcare $(\mathrm{PHC})$ services and identify specific populations that have differentiated access to health services.

\section{METHOD}

This study is an integrative review of the literature on access to primary health care. During its development, the authors systematically sought to identify articles from different databases that addressed the study questions and supported this discussion.

To systematize the integrative review, the following steps were followed ${ }^{(8-9)}$ : Identification of theme, study questions and objectives; definition of databases and inclusion and exclusion criteria; definition of the information to be extracted and categorization; evaluation of the studies included in the review by at least two researchers and, in case of disagreement, by a third researcher to avoid bias; interpretation of results; presentation of the review, and knowledge synthesis.

When searching studies on databases, the key words from Medical Subject Headings (MeSH) were selected. We combined four key words selected as search strategy using the Boolean operator "and" to obtain more significant results: (1) "Health Care Accessibility," "Primary Health Care" and "Health Care Reform;" and (2) "Rural settlements." The articles were searched on the following databases: MEDLINE (PubMed), SciVerse Scopus (Scopus), The Cumulative Index to Nursing and Allied Health Literature (CINAHL), and the Regional Portal of Biblioteca Virtual em

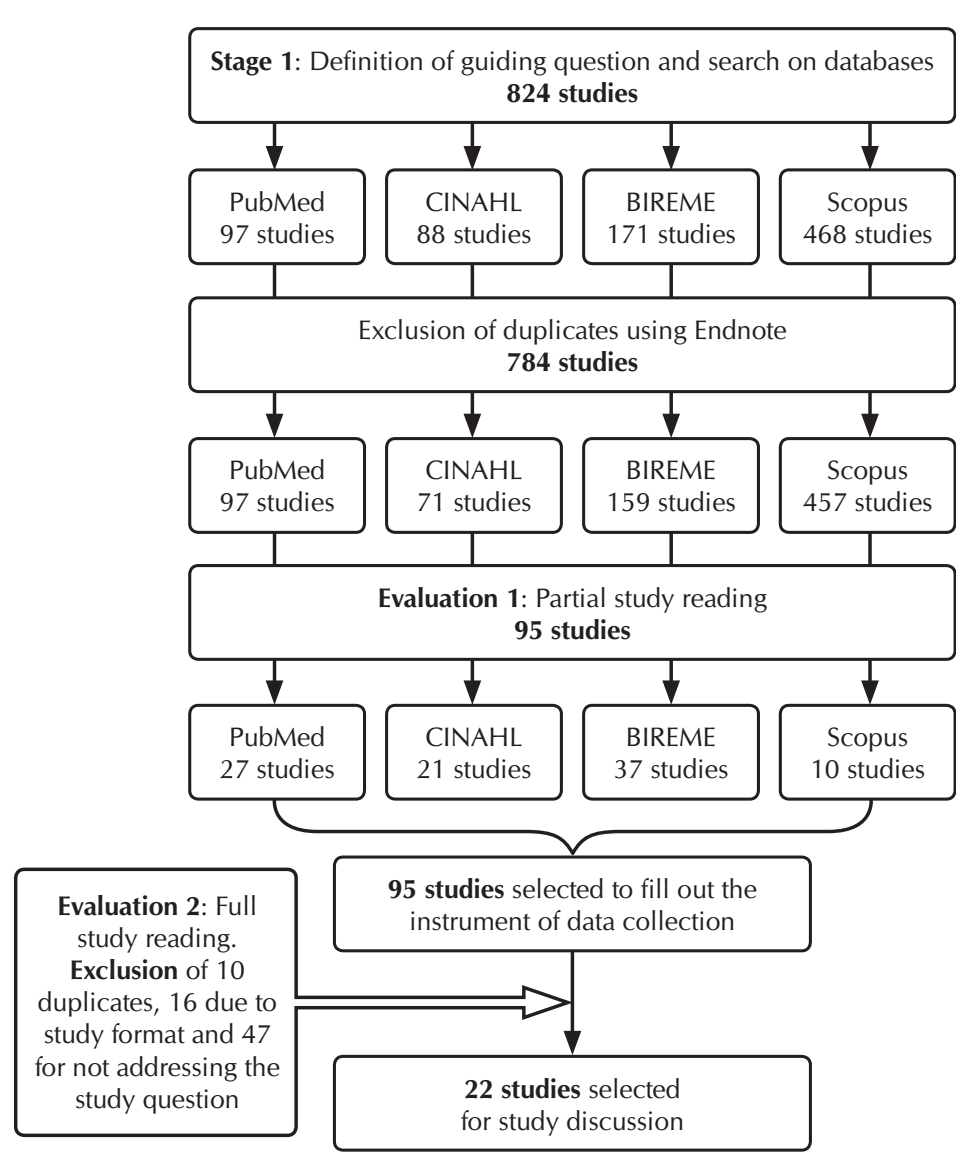

Figure 1 - Flowchart of study search and selection on databases, 2016 
Saúde (BIREME). The search was conducted from September 2016 to January 2017. Articles in Portuguese, English or Spanish published between 2012 and 2016 (five years) that addressed the study theme were selected.

In the first step, 824 studies were selected and exported to the EndNote reference manager. After that, 40 duplicates were deleted from the manager, leading to 784 studies. Titles and abstracts were reviewed by two examiners and 689 studies were excluded because they were not considered relevant to the study, totaling 95 articles (Figure 1). These 95 articles were read in full, using an instrument to collect information such as: author, title, journal/ year of publication, database, objective, methodology, main results and conclusions/recommendations of the study.

During this second evaluation, the instrument was filled out, and again some articles were excluded following these criteria: 10 duplicates that had not been identified before by the EndNote reference manager; 16 were not full studies and 47 did not address the study questions (Figure 1).

\section{RESULTS}

In total 22 studies were selected from 2012 to 2015 for this integrative review. Studies from BIREME database were predominant $(59 \%)$, followed by PubMed (22\%). Most studies were in English - 19 articles - and three were in Portuguese. Regarding the study methodology, most studies used a qualitative approach (11) followed by a quantitative method (seven), literature review (two), and a combination of qualitative and quantitative methods (two).

The studies were conducted in 11 different regions of the world: eight in the United States of America, four in Brazil, two in Australia, and one in each of the following regions: Ecuador, Greece, Iran, Japan, Malaysia, New Zealand, the Baltic States, and Suriname.

The description of the studies is presented according to the convergent themes for the analysis by category, based on the guiding questions of the publications of how the access to health services occurs in countries and regions and what specific populations, such as settlers, quilombolas, aborigines and immigrants, have a differentiated access. Three groups were created according to selected studies: access of specific populations to health services (Chart 1: five studies), access to primary health care through health plans (Chart 2: five studies), and proposed improvements to health care access (Chart 3: 12 studies).

\section{Access of specific populations to health services}

When analyzing the studies, the possibilities of access or lack of access of specific populations to health services demonstrated in some countries were highlighted.

Chart 1 - Description of studies on the access of specific populations to health services, according to authors, year of publication, journal, country, objective, methodology, and main results, 2016

\begin{tabular}{|c|c|c|c|}
\hline $\begin{array}{c}\text { Authors/journal/ } \\
\text { country }\end{array}$ & Objective & Method & Main results \\
\hline $\begin{array}{l}\text { Vargas BA et al. }{ }^{(10)} \\
(2012) \\
\text { J Immigr Minor } \\
\text { Health } \\
\text { USA }\end{array}$ & $\begin{array}{l}\text { Identify differences in } \\
\text { the access to healthcare } \\
\text { services of documented or } \\
\text { undocumented Mexican } \\
\text { immigrants in the USA. }\end{array}$ & $\begin{array}{l}\text { Quantitative: data from the } \\
\text { California Health Interview Survey } \\
\text { (CHIS) (population study conducted } \\
\text { by telephone). Chi-square tests to } \\
\text { determine access. }\end{array}$ & $\begin{array}{l}\text { Documented immigrants are likely to see } \\
\text { a physician at least once. Undocumented } \\
\text { immigrants excluded from the Patient } \\
\text { Protection and Affordable Care Act do not } \\
\text { have access to health services. }\end{array}$ \\
\hline $\begin{array}{c}\text { Santos JCB, } \\
\text { Hennington EA } \\
\text { (2013) } \\
\text { Cad Saúde Pública } \\
\text { Brazil }\end{array}$ & $\begin{array}{l}\text { Analyze the lifestyles and } \\
\text { meanings attributed by } \\
\text { settlers from the landless } \\
\text { rural workers' movement } \\
\text { (MST - Movimento dos } \\
\text { Trabalhadores Rurais Sem } \\
\text { Terra) to health and their } \\
\text { relationships with labor; } \\
\text { identify strategies of health } \\
\text { promotion/maintenance. }\end{array}$ & $\begin{array}{l}\text { Qualitative: documentary analysis; } \\
\text { community observation; } 11 \\
\text { interviews and focus group; content } \\
\text { analysis. }\end{array}$ & $\begin{array}{l}\text { The settlers attribute freedom and } \\
\text { satisfaction, self-management and } \\
\text { autonomy to work, which are considered } \\
\text { essential for health. Health access: } \\
\text { need to travel to neighboring cities to } \\
\text { use services; lack of health care; use of } \\
\text { medicinal plants as an alternative due to } \\
\text { lack of access. }\end{array}$ \\
\hline $\begin{array}{l}\text { Moss JA }^{(12)} \\
(2014) \\
\text { Invest Educ Enferm } \\
\text { Ecuador }\end{array}$ & $\begin{array}{l}\text { Discover and understand } \\
\text { health-related beliefs } \\
\text { and practices of mestizo } \\
\text { Ecuadorians in rural areas of } \\
\text { Ecuador. }\end{array}$ & $\begin{array}{l}\text { Qualitative: semi-structured } \\
\text { interviews ( } 28 \text { interviewees) } \\
\text { and observation. Leininger's } \\
\text { transcultural nursing. Analysis: } \\
\text { Qualitative software NVIVO8. }\end{array}$ & $\begin{array}{l}\text { Healer is a primary, secondary or } \\
\text { tertiary health resource and/or the use of } \\
\text { medicinal plants. } \\
\text { They present many needs and multiple } \\
\text { barriers in health care. }\end{array}$ \\
\hline $\begin{array}{l}\text { Santos RC, Silva, } \\
\text { MS }^{(13)}(2014) \\
\text { Saude Soc } \\
\text { Brazil }\end{array}$ & $\begin{array}{l}\text { Investigate the health } \\
\text { conditions and therapies } \\
\text { of the individuals from two } \\
\text { quilombola communities in } \\
\text { Goiás. }\end{array}$ & $\begin{array}{l}\text { Quantitative and qualitative: } \\
\text { questionnaire with heads of } 52 \\
\text { families ( } 188 \text { people); semi-structured } \\
\text { interviews with key interviewees and } \\
\text { participant observation. }\end{array}$ & $\begin{array}{l}\text { Results classified according to the thematic } \\
\text { axes: living conditions, health services, } \\
\text { and therapies. They face difficult access to } \\
\text { quality basic public health services. }\end{array}$ \\
\hline
\end{tabular}

To be continued 


\begin{tabular}{|c|l|l|l|}
\hline $\begin{array}{c}\text { Authors/journal/ } \\
\text { country }\end{array}$ & \multicolumn{1}{c|}{ Objective } & Method & \multicolumn{1}{c|}{ Main results } \\
\hline $\begin{array}{c}\text { Wunsch S et al. }{ }^{(14)} \\
\text { (2014) } \\
\begin{array}{c}\text { Rev Gaucha } \\
\text { Enferm } \\
\text { Brazil }\end{array}\end{array}$ & $\begin{array}{l}\text { Learn about healthcare } \\
\text { practices in the perspective } \\
\text { of families living in a rural } \\
\text { settlement in the northwest } \\
\text { region of the State of Rio } \\
\text { Grande do Sul. }\end{array}$ & $\begin{array}{l}\text { Qualitative: ethnography } \\
\text { Observation- Participation- } \\
\text { Reflection Model. }\end{array}$ & $\begin{array}{l}\text { Poor rural settlements make it difficult } \\
\text { for families to access health services. } \\
\text { Families live with scarce service coverage } \\
\text { and they use their cultural background for } \\
\text { the necessary health care. }\end{array}$ \\
\hline
\end{tabular}

Chart 2 - Access to primary health care according to authors, year of publication, journal, country, objective, methodology, and main results, 2016

\begin{tabular}{|c|c|c|c|}
\hline $\begin{array}{l}\text { Authors/journal/ } \\
\text { country }\end{array}$ & Objective & Method & Main results \\
\hline $\begin{array}{l}\text { Bond AM, White } \\
\text { C(15) }^{(2013)} \\
\text { Health Serv Res } \\
\text { USA }\end{array}$ & $\begin{array}{l}\text { Analyze whether expanding } \\
\text { coverage for non-elderly } \\
\text { adults has affected the use of } \\
\text { primary care among Medicare } \\
\text { users in Massachusetts. }\end{array}$ & Quantitative: Medicare database. & $\begin{array}{l}\text { Compared to other states, there was a } \\
6.7 \% \text { increase in visits to a primary health } \\
\text { care physician in Medicare and a } 7 \% \\
\text { decrease in population without an annual } \\
\text { visit to a primary health care physician. }\end{array}$ \\
\hline $\begin{array}{c}\text { Dow AW et al. }{ }^{(16)} \\
(2013) \\
\text { Acad Med } \\
\text { USA }\end{array}$ & $\begin{array}{l}\text { Compare Virginia } \\
\text { Coordinated Care (VCC) } \\
\text { insurance to the Patient } \\
\text { Protection (PP) and } \\
\text { Affordable Care Act (ACA). }\end{array}$ & $\begin{array}{l}\text { Quantitative: data from VCC. } \\
\text { Exposed groups of medical } \\
\text { complexity: SpecifCare }(1.2 \%) \text {, } \\
\text { EpisodiCare }(62 \%) \text {, CroniCare } \\
(16.4 \%), \text { ComplexiCare }(8.7 \%) .\end{array}$ & $\begin{array}{l}\text { In the comparison of Virginia Coordinated } \\
\text { Care to the Patient Protection and } \\
\text { Affordable Care Act, to improve the access, } \\
\text { it is necessary to expand the access to } \\
\text { primary care services, therapeutic residency } \\
\text { for chronic diseases, and the continued } \\
\text { training of health professionals. }\end{array}$ \\
\hline $\begin{array}{l}\text { Cheng TL, Wise } \\
\text { PH, Halfon N }{ }^{(17)} \\
(2014) \\
\text { Pediatrics } \\
\text { USA }\end{array}$ & $\begin{array}{l}\text { Expand ideas on the impact } \\
\text { of the Affordable Care Act } \\
\text { on the health of American } \\
\text { children. }\end{array}$ & $\begin{array}{l}\text { Quantitative: a practical state } \\
\text { checklist tool was used. }\end{array}$ & $\begin{array}{l}\text { It was found that the plan coverage does } \\
\text { not ensure the availability of primary care } \\
\text { to children, the main factors are: difficult } \\
\text { accessibility, family non-enrollment, } \\
\text { immigration and non-proficiency in English } \\
\text { language. }\end{array}$ \\
\hline $\begin{array}{l}\text { Rhodes K et al. }{ }^{(18)} \\
(2014) \\
\text { JAMA Intern Med } \\
\text { USA }\end{array}$ & $\begin{array}{l}\text { Analyze the availability } \\
\text { of visits to primary health } \\
\text { care physicians by state and } \\
\text { status of health insurance. }\end{array}$ & $\begin{array}{l}\text { Quantitative: phone contacts were } \\
\text { performed from primary care office } \\
\text { in } 10 \text { American states }(11,347 \text { calls } \\
\text { were made). }\end{array}$ & $\begin{array}{l}\text { More appointments available for private } \\
\text { insurance than for Medicaid. In the states, } \\
\text { the calls to schedule a primary care } \\
\text { appointment for Medicaid patients were } \\
\text { worse than for patients of private plans. }\end{array}$ \\
\hline $\begin{array}{l}\text { Ortega NA, } \\
\text { Rodriguez HP, } \\
\text { Vargas BA }{ }^{(19)} \\
\text { (2015) } \\
\text { Annu Rev Public } \\
\text { Health } \\
\text { USA }\end{array}$ & $\begin{array}{l}\text { Perform a review on health } \\
\text { policies and services that affect } \\
\text { the Latin immigrants living in } \\
\text { the United States and that are } \\
\text { relevant to understanding the } \\
\text { impact of ACA on the health of } \\
\text { this population. }\end{array}$ & Literature review. & $\begin{array}{l}\text { Latin immigrants have worse geographic } \\
\text { access to health care in the United States } \\
\text { due to migration; because they live } \\
\text { in rural areas; or language issues with } \\
\text { health professionals. The Affordable Care } \\
\text { Act should make preventive care more } \\
\text { accessible to Latin immigrants. }\end{array}$ \\
\hline
\end{tabular}

Chart 3 - Description of studies on proposed improvements to access to primary health care, according to authors, year of publication, journal, country, objective, methodology, and main results, 2016

\begin{tabular}{|c|l|l|l|}
\hline $\begin{array}{c}\text { Authors/journal/ } \\
\text { country }\end{array}$ & \multicolumn{1}{|c|}{ Objective } & Method & \multicolumn{1}{c|}{ Main results } \\
\hline $\begin{array}{c}\text { Grant R, Greene D(20) } \\
\text { (2012) }\end{array}$ & $\begin{array}{l}\text { Summarize the model } \\
\text { of nursing home and the } \\
\text { evidence of its public health } \\
\text { and clinical efficacy. }\end{array}$ & $\begin{array}{l}\text { Qualitative: narrative on the model of } \\
\text { nursing home as a means to help PHC } \\
\text { achieve the objectives of increasing } \\
\text { access to care, reduce disparities } \\
\text { and integrate care with public health } \\
\text { systems. }\end{array}$ & $\begin{array}{l}\text { The model of nursing home increases } \\
\text { access of low-income people and racial/ } \\
\text { ethnic minorities. Nursing home provides } \\
\text { health insurance, transportation, long } \\
\text { service hours and integration of the main } \\
\text { specialized services. }\end{array}$ \\
\hline
\end{tabular}




\begin{tabular}{|c|c|c|c|}
\hline $\begin{array}{l}\text { Authors/journal/ } \\
\text { country }\end{array}$ & Objective & Method & Main results \\
\hline $\begin{array}{l}\text { Jiwa M et al. }{ }^{(21)} \\
(2012) \\
\text { Qual Prim Care } \\
\text { Malaysia }\end{array}$ & $\begin{array}{l}\text { Case report on the Asian } \\
\text { health system, using the } \\
\text { example in Malaysia. }\end{array}$ & $\begin{array}{l}\text { Qualitative: case report on the } \\
\text { health system in Malaysia. }\end{array}$ & $\begin{array}{l}\text { The primary health system offered by } \\
\text { the government is the main provider } \\
\text { of health care. Most Malaysians have } \\
\text { excellent access to health care. A } \\
\text { significant percentage of residents in } \\
\text { the east part of the country and the } \\
\text { Aborigines have limited access. }\end{array}$ \\
\hline $\begin{array}{c}\text { Tan L, Carr J, Reidy } \\
\text { J (22) }^{(2012)} \\
\text { NZMJ } \\
\text { New Zealand }\end{array}$ & $\begin{array}{l}\text { Provide evidence on the } \\
\text { effectiveness of investments } \\
\text { in primary health care in } \\
\text { New Zealand. }\end{array}$ & $\begin{array}{l}\text { Quantitative and qualitative: the } \\
\text { effectiveness of investments was } \\
\text { measured through the District } \\
\text { Health Council, the Capital Council } \\
\text { and PHC indicators. }\end{array}$ & $\begin{array}{l}\text { The study observed increased and } \\
\text { redistributed primary care and workforce, } \\
\text { increased availability of general } \\
\text { practitioners, and allocation of community } \\
\text { workers to poorer areas. There was also a } \\
\text { reduction in outpatient hospitalization and } \\
\text { use of emergency services. }\end{array}$ \\
\hline $\begin{array}{l}\text { Polluste K et al. }{ }^{(7)} \\
\text { (2013) } \\
\text { Health Policy } \\
\text { The Baltic States }\end{array}$ & $\begin{array}{l}\text { Monitor indicators of access } \\
\text { to PHC, continuity of care, } \\
\text { and aspects of patient } \\
\text { experience to discuss the } \\
\text { suitability of PHAMEU in } \\
\text { comparison to primary care } \\
\text { systems. }\end{array}$ & $\begin{array}{l}\text { Quantitative: the study used } \\
\text { PHAMEU to monitor primary care } \\
\text { activity in Europe (it covered the } \\
27 \text { Member States of the European } \\
\text { Union, plus Turkey, Iceland, } \\
\text { Norway, and Switzerland). }\end{array}$ & $\begin{array}{l}\text { In Lithuania, the access policy is not } \\
\text { well defined. In the Baltic States, } \\
\text { the organizations of physicians or } \\
\text { patients for care contribute informally } \\
\text { to primary care policies. For family } \\
\text { medicine, some hours of work should } \\
\text { be dedicated to priority appointments. } \\
\text { For the comparison of health systems, } \\
\text { each country should use its own forms } \\
\text { to organize its data. }\end{array}$ \\
\hline $\begin{array}{l}\text { Groenewegen PP, } \\
\text { Jurgutis A }{ }^{(23)} \\
(2013) \\
\text { Qual Prim Care } \\
\text { Greece }\end{array}$ & $\begin{array}{l}\text { Assess the situation of } \\
\text { primary care provided to the } \\
\text { Greek population. }\end{array}$ & $\begin{array}{l}\text { Qualitative: The assessment } \\
\text { of primary care in Greece was } \\
\text { conducted using the existing } \\
\text { literature, visits to primary care } \\
\text { centers and consultations with } \\
\text { stakeholders. }\end{array}$ & $\begin{array}{l}\text { Governance is fragmented. There is } \\
\text { no system of patient lists; the private } \\
\text { payments are high. There are many } \\
\text { physicians, but few general practitioners } \\
\text { and nurses, and they are distributed } \\
\text { irregularly in the country, resulting in } \\
\text { difficult primary care access, continuity, } \\
\text { coordination and coverage. }\end{array}$ \\
\hline $\begin{array}{l}\text { Thomas SL, } \\
\text { Wakeman J, } \\
\text { Humphreys JS (24) } \\
(2014) \\
\text { BMC Fam Pract } \\
\text { Australia }\end{array}$ & $\begin{array}{l}\text { Provide a model to policy } \\
\text { makers, service providers, } \\
\text { and users, determining } \\
\text { which primary care services } \\
\text { should be available to all } \\
\text { Australians. }\end{array}$ & $\begin{array}{l}\text { Quantitative: Delphi's method was } \\
\text { used to reach a consensus among } \\
39 \text { specialists (from rural, remote } \\
\text { and/or indigenous primary health } \\
\text { care) regarding the list of services } \\
\text { that should be available. A Liket } \\
\text { scale was used to prioritize the } \\
\text { services. }\end{array}$ & $\begin{array}{l}\text { High-consensus services were: care } \\
\text { to people with diseases and injuries, } \\
\text { maternal and child health, disease } \\
\text { prevention and oral health, quality and } \\
\text { accessibility. For support to services: } \\
\text { management/governance/leadership and } \\
\text { coordination. Difficult recruitment and } \\
\text { maintenance of qualified professionals, } \\
\text { in extended infrastructure, quality } \\
\text { assurance and accessibility. }\end{array}$ \\
\hline $\begin{array}{c}\text { Bodenheimer T et al. }{ }^{(25)} \\
(2014) \\
\text { Ann Fam Med } \\
\text { USA }\end{array}$ & $\begin{array}{l}\text { Formulate essential elements } \\
\text { of primary care, called 'the } \\
10 \text { building blocks' of high- } \\
\text { performance primary care. }\end{array}$ & $\begin{array}{l}\text { Qualitative: case study; data were } \\
\text { analyzed from health sites on } 23 \\
\text { practices of PHC, experience of } \\
\text { two researchers as enablers in } \\
\text { more than } 25 \text { practices, review of } \\
\text { existing models and studies on PHC } \\
\text { improvements. }\end{array}$ & $\begin{array}{l}\text { The } 10 \text { building blocks were: } \\
\text { leadership; improvements based on } \\
\text { indicators; care services provided by } \\
\text { team; partnership between patients and } \\
\text { the team; population management; care } \\
\text { continuity; quick access; understanding } \\
\text { and coordination of care, and proposed } \\
\text { models for the future of PHC services. }\end{array}$ \\
\hline $\begin{array}{c}\text { Aguilera CCE, } \\
\text { Brandão AL, Bocater } \\
\operatorname{PPM}^{(26)}(2014) \\
\text { Physis } \\
\text { Brazil }\end{array}$ & $\begin{array}{l}\text { Investigate the dimensions } \\
\text { that are most valued by users } \\
\text { of health services. }\end{array}$ & $\begin{array}{l}\text { Qualitative: focal groups and } \\
\text { content analysis. }\end{array}$ & $\begin{array}{l}\text { The results produced in total } 17 \\
\text { dimensions. The most frequently } \\
\text { mentioned were: service access and } \\
\text { availability; work process organization; } \\
\text { relationship with health professionals; } \\
\text { longitudinality; and link between } \\
\text { professionals, users, and care } \\
\text { coordination. }\end{array}$ \\
\hline
\end{tabular}




\begin{tabular}{|c|c|c|c|}
\hline $\begin{array}{l}\text { Authors/journal/ } \\
\text { country }\end{array}$ & Objective & Method & Main results \\
\hline $\begin{array}{l}\text { Esmaeili R et al. }{ }^{(27)} \\
\text { (2015) } \\
\text { Glob J Health Sci } \\
\text { Iran }\end{array}$ & $\begin{array}{l}\text { Understand the perspectives } \\
\text { of Iran's political decision- } \\
\text { makers and health system on } \\
\text { the implementation of family } \\
\text { medicine in urban areas of } \\
\text { the country. }\end{array}$ & $\begin{array}{l}\text { Qualitative: interviews with policy } \\
\text { makers of five main organizations } \\
\text { in family physician project ( } 27 \\
\text { interviews). Method: framework for } \\
\text { data analysis. }\end{array}$ & $\begin{array}{l}\text { The perspectives indicate the family } \\
\text { medicine project implementation will } \\
\text { support physician visits, extended care } \\
\text { and the creation of reference networks. } \\
\text { They understand family medicine } \\
\text { improves financial and geographical } \\
\text { access to health. }\end{array}$ \\
\hline $\begin{array}{c}\text { Reeve C et al. }{ }^{(28)} \\
(2015) \\
\text { Med J Aust } \\
\text { Australia }\end{array}$ & $\begin{array}{l}\text { Assess the impact of a } \\
\text { service model of PHC using } \\
\text { key performance indicators } \\
\text { in health and the association } \\
\text { with increased use of health } \\
\text { care in a remote region of } \\
\text { Australia. }\end{array}$ & $\begin{array}{l}\text { Quantitative: document analysis, } \\
\text { evaluated according to } \\
\text { the National Key Performance } \\
\text { Indicators for Aboriginal and Torres } \\
\text { Strait Islander for PHC, with non- } \\
\text { parametric trend test, Stata version } \\
10 \text { (StataCorp). }\end{array}$ & $\begin{array}{l}\text { The study observed that the increase of } \\
\text { political and structural actions resulted } \\
\text { in } \\
\text { increased primary care activity, thus } \\
\text { reducing the flow of urgent services. } \\
\text { A general increase was observed in } \\
\text { the access to primary care services, } \\
\text { especially by peripheral communities. }\end{array}$ \\
\hline $\begin{array}{l}\text { Takamura A } A^{(29)} \\
(2015) \\
\text { Qual Prim Care } \\
\text { Japan }\end{array}$ & $\begin{array}{l}\text { Present an investigation into } \\
\text { the history of primary care } \\
\text { in Japan and show current } \\
\text { problems and situations. }\end{array}$ & $\begin{array}{l}\text { Qualitative: case report that } \\
\text { addresses the "Primary Care in } \\
\text { Japan" in terms of History of } \\
\text { Primary Care, Medical System and } \\
\text { Medical Education. }\end{array}$ & $\begin{array}{l}\text { Currently, the Japanese government } \\
\text { is trying to introduce the General } \\
\text { Practitioner / Family Physician (GP/FP) } \\
\text { to improve cost-effectiveness ratio and } \\
\text { provide better care to the population. They } \\
\text { propose to change the medical education } \\
\text { training model to prioritize primary care. }\end{array}$ \\
\hline $\begin{array}{c}\text { Larye S, Goede H, } \\
\text { Barten } \\
\mathrm{F}^{(30)} \\
(2015) \\
\text { Rev Panam Salud } \\
\text { Publica } \\
\text { Suriname }\end{array}$ & $\begin{array}{l}\text { Provide an overview } \\
\text { of the development } \\
\text { and implementation of } \\
\text { comprehensive primary } \\
\text { health care in Suriname. }\end{array}$ & $\begin{array}{l}\text { Literature review: three articles } \\
\text { selected and analyzed. }\end{array}$ & $\begin{array}{l}\text { There is a shortage of studies on this } \\
\text { theme. Partial views of primary care are } \\
\text { observed in the country and examples } \\
\text { of practice. Focus on the service } \\
\text { network is observed in the country side } \\
\text { to improve rural access, training the } \\
\text { community members for support. }\end{array}$ \\
\hline
\end{tabular}

One study ${ }^{(12)}$ investigated the health situation, practices and beliefs of rural mestizos from Ecuador, the role of nurses in rural areas of Ecuador, and the implications for care provision to this group in the future. The village of Tosagua has no intensive care or urgent care center; there are drugstores in the area, only three doctors and folk healers, who provided the first care. Other services are provided more than an hour away, in a larger city ${ }^{(12)}$.

In Brazil, two studies on settlers ${ }^{(11,14)}$ analyzed the lifestyles, the meanings attributed to health and their relationships with work, identifying the strategies developed by workers to maintain and / or promote health. Problems of health access were highlighted by the settlers, referring to the need to travel to neighboring cities where services are offered, and the challenges and lack of care in these places. Medicinal plants are used individually or by families, and are sometimes the first choice for disease treatment due to the difficult access to health services ${ }^{(11,14)}$.

Also in Brazil, in quilombola communities in the state of Goiás, the living conditions and their therapeutic options were studied, such as: the distance between the community and the services; the staff turnover in the Basic Health Units, due to community infrastructure and the underestimation of the professionals regarding the effectiveness of home remedies. The communities present difficult access and quality issues in basic public services; however, social networks of family members and neighbors and traditional habits lead to different therapeutic options ${ }^{(13)}$.

In the United States of America (USA), a study sought to identify differences in access to and use of health services by documented and undocumented Mexican immigrants ${ }^{(10)}$. Documented immigrants are more likely to have at least one visit to a physician. English language issues and the time an immigrant has lived in the United States are significant factors when explaining differences in access to and use of health care services. The exclusion of undocumented immigrants from the Patient Protection (PP) and Affordable Care Act (ACA) promotes less equitable access to and use of health services when comparing documented and undocumented immigrants ${ }^{(10)}$.

\section{Access to primary health care through health plans}

Studies that address the use and a comparison of health plans for access to primary care are included in this review, such as those implemented in the United States: Medicaid, Patient Protection, Affordable Care Act, Child Health Insurance Program, and Virginia Coordinated Care.

One study ${ }^{(15)}$ analyzed Medicaid in the population of Massachusetts and its trends in the useof primary care services. In 2006, there was a policy change at the state level, and health reform significa ntly increased insurance coverage among non-elderly people, unlike other nearby states. Then, 
the areas of greater insurance expansion presented increased use of primary care services and, consequently, a decrease in hospitalization compared to other areas.

Following the ACA implementation, there was a concern about the future situation of the Child Health Insurance Program (CHIP), since a child's eligibility for health insurance does not ensure enrollment and access. For example, in 2009, around two thirds of the children were eligible for insurance but they were not in Medicaid or CHIP. The enrollment process is not accessible to families with poor English skills ${ }^{(17)}$. Cheng et al. ${ }^{(17)}$ observe that the presence of pediatric professionals in primary care participating in all public and private insurance plans is required to ensure care quality, continuity and access.

Dow et al. ${ }^{(16)}$ conducted a study that compared Virginia Coordinated Care (VCC) to PP and ACA programs, using the VCC database to obtain the clinical data of patients enrolled in the program. Four categories of medical complexity were developed: SpecifCare, for patients with specialized diagnosis (HIV, neoplasm, substance abuse, etc.); EpisodiCare, for minor clinical complexities; CroniCare, for intermediate clinical complexities; and ComplexiCare, for patients with major clinical complexities. Based on these data, $62 \%$ of the patients were classified as EpisodiCare, and most patients of this group had never seen a primary care physician under the VCC by 2012.

The suggestion to improve access is the provision of therapeutic residency services to patients with chronic diseases and continued training to health professionals so that they are prepared for changes in Health Care Policies.

The study evaluated the availability of primary care appointments for new patients near the ACA reform by state and insurance status. They simulated appointment schedule to check the availability of primary care appointments at these sites for non-elderly adults in 10 American states. For those who were able to make any appointment, the average waiting time ranged from five to eight days for both private and Medicaid insurance, with greater access to private insurance ${ }^{(18)}$.

In terms of insurance for specific groups, Latin immigrants have the worst geographical access to health care in the United States, often due to migration or because they live in rural areas. They receive less comprehensive care, usually because of language issues with health professionals. According to estimates, if all states participated in the Medicaid expansion program, 95\% of uninsured Latin immigrants would be qualified for insurance. In 2012, the US Supreme Court offered voluntary expansion of ACA Medicaid to state governments. If ACA was implemented, preventive care would be more affordable to Latin immigrants, since it regulations require most insurance plans should offer preventive care without increasing costs ${ }^{(19)}$.

\section{Proposed improvements in access to primary health care services}

Based on the analyzed studies, this review observed that, for this category, some countries have provided proposals for structuring, organizing or implementing practices that provide better access to primary health care.

Bodenheimer et al. ${ }^{(25)}$, when analyzing exemplary PHC practices and other patient-oriented practices, formulated so-called '10 primary care building blocks.' These blocks include four key elements that are: 'committed leadership', referring to high-performance practices with leaders who create goals, objectives, and are committed to the change process; 'data-based improvement', which monitors existing indicators; 'empanelment,' which relates each patient to a team to improve care continuity and the partnership between both; and 'teamwork,' which refers to the practices performed by teams. These four blocks help implement the other six building blocks: patient team, population management, care continuity, quick access to care, care coverage (coordination), and a model for the future ${ }^{(25)}$.

In Europe, researchers used an instrument called Monitoring the Primary Health Care Activity for Europe (PHAMEU) to monitor indicators like access to PHC, care continuity and some aspects of patient experience. The PHAMEU project covered all 27 Member States of the European Union, plus Turkey, Iceland, Norway, and Switzerland. In all the Baltic States, organizations of primary care stakeholders (that is, professional medical or patient organizations) contributed to the development of PHC policies ${ }^{(7)}$.

A model of nursing home was approved at the end of 2010 by the American Public Health Association as a means for primary care to contribute to public health goals and increase the access to health care by reducing disparities and improving integration of care with public health systems. This model emphasizes continuous, comprehensive, coordinated and familycentered care, and it prioritizes low-income, racial and ethnic minorities with poor access to quality services ${ }^{(20)}$.

The primary health care system in Malaysia was used by administrators to design solutions for health challenges across Asia. The system is funded by the government, and it is the main service provider, with expenses reaching $58.4 \%$ of the total national health budget in 2006, so it proposed a reform of the health financing system. While most Malaysians have excellent access to health care, a significant proportion, particularly those with modest conditions, living in the east region of the country and the Malaysian Aborigines, have limited access ${ }^{(21)}$.

Primary health care is considered a priority in the provision of quality health care to chronic disease and to improve the cost-benefit ratio for Malaysians. Despite significant progress, infrastructure development and care services, Malaysia, whether in the public or private sector, is still focused on acute, episodic, chronic disease care, as well as maternal and child health ${ }^{(21)}$.

In Australia, a remote region, the impact of a comprehensive model of PHC services (partnership between an Aboriginal community-controlled health service, a hospital and a community health service in the northwest region of Western Australia) was analyzed using the main indicators of health performance and analysis of how changes in the service delivery model were associated with increased use of primary health care $^{(28)}$. Also in Australia, another study proposed a model for policy makers, service providers and users, determining which primary care services should be available to Australians living in rural and remote communities (list of essential support services and functions in $\mathrm{PHC})^{(24)}$. 
The services that obtained the greatest consensus among the specialists were: care to people with diseases and injuries, maternal and child health, health prevention, and oral health. In terms of support, the consensus is in management/governance/leadership and coordination. Some of the challenges related to the provision of identified services included difficult recruitment and maintenance of qualified professionals, infrastructure maintenance and extension, quality assurance and service security, and guarantee of accessibility ${ }^{(24)}$.

In New Zealand, major investments were made in $\mathrm{PHC}$, with subsequent evaluation of the impact on health care to demonstrate the need for broader health policies. The findings were: increased access to primary care of poor population and other ethnic groups, reduction of outpatient hospitalization and use of emergency services, increased coverage of immunization, workforce redistribution, and consequently, improved health outcomes ${ }^{(22)}$.

In Brazil, a study investigated the dimensions that are most valued by patients in the health services for the development of more adequate instruments to support PHC. The study found a total of 17 dimensions, including: access and availability of health services; organization of work processes; relationship with professionals; care longitudinality and link between professionals and users; and care coordination ${ }^{(26)}$.

In Japan, due to quick aging of population, increased expenses and foreign pressure on medical education, major changes were required in health care, especially in primary care. However, primary care development and situations are characteristic and specific, when compared to other Western countries, but the definition of 'primary care' in Japan is ambiguous, differing from the general practice in the United Kingdom or family medicine in the United States ${ }^{(29)}$.

Medicare started in 1961 and it is the national health insurance in Japan; all Japanese citizens have to join the system, which in general covers $70 \%$ of fees related to appointments, exams and treatments in all health facilities. It means that the rates are not decided by the care provider (specialist or general practitioner) or where the health center (tertiary or primary clinic), but only by the characteristic of the care provided. The clinics are well equipped and the physicians tend to request many costly exams, but the amount paid by the patients is low. The access to any physician and care is free, and patients can choose a specialist without referral from a general practitioner, sometimes without a scheduled appointment, and usually they do not have to wait too long ${ }^{(29)}$.

In Greece, primary health care is fragmented. There is no system of patient list and the costs of private sector are high. It has many physicians, but few general practitioners and nurses, who are disorderly distributed across the country. The study shows that professional training should emphasize primary care, and the specialists who work in this field should be (re-)trained to acquire the required skills and meet the primary care needs ${ }^{(23)}$.

In this review, three studies were selected which provided partial views of the Comprehensive Primary Health Care (CPHC) in Suriname and examples of its implementation, focusing on the country's service provision network, designed to improve rural access to basic health services by training community members to act as service providers. The right to health of individuals is supported, the State's role is to protect public health, and the Ministry of Health supervises the services to ensure care quality, availability, and accessibility. Policlinics (clinics offering outpatient services, including diagnosis) provide services to a large part of the coastal population, including the poor and 'near poor' population, who are identified by the Ministry of Social Affairs (MSA) in the country ${ }^{(30)}$.

In the country side, a non-governmental organization (NGO) named Medische Zending (MZ), provides PHC services. Health workers are trained and supervised by a small group of nurses registered in the $M Z^{(30)}$.

In Iran, understanding the perspectives of policy makers and the health system in terms of family medicine implementation in urban areas of the country has resulted in a consensus among interviewees that a referral network is required in the Iranian system, ensuring higher relevance to the family physician project. Decision makers believe this project implementation will promote people's access to appointments and that health care will be evenly provided across all urban areas, especially in remote areas. The results indicated that Iranian policymakers and health care organizations consider family medicine as a viable way to promote a number of crucial reforms in the country's health system ${ }^{(27)}$.

\section{DISCUSSION}

After reviewing the literature, the access to health care in international scenarios was analyzed, in terms of ensuring or not the access to PHC by specific populations ${ }^{(10-14)}$; some studies show the access through health plans ${ }^{(15-19)}$; or address possibilities or proposals to improve the access to services either through restructuring ${ }^{(23-27,29)}$ or strategies implemented for this purpose $^{(7,20-22,28,30)}$.

Considering the theme of access to PHC, popular health care practices and beliefs, such as medicinal plants, healers, among others, are still the first alternative to health issues in rural communities in some countries, especially in Ecuadorians rural communities, and settlements and quilombola communities in Brazil ${ }^{(11-14)}$. Ethnic-racial and economic differences are still sources of social inequities in studied populations ${ }^{(13)}$.

These communities report difficult access to the health system, requiring long, and sometimes unplanned, trips. Therefore, their first resource is to use what they have in the community itself. Some reports ${ }^{(13)}$ emphasize that health professionals underestimate the use of alternative therapies, providing cultural and belief conflicts in their use with these populations.

Regarding the immigrant populations in the United States, for the access to health care, there is a difference between undocumented and documented immigrants ${ }^{(10)}$. Undocumented immigrants are less likely to have a usual source of care because they are excluded from the PP and ACA.

Regarding care continuity, referred to in the studies as the follow-up practice, this review observed a concern about structuring ways to link the patient with health teams for continuous and integral follow-up, encouraging teamwork, and monitoring of access and continuity indicators for more 
effective implementations ${ }^{(7,20,22,25)}$, but it is not very clear in most studies. In a study conducted in Brazil, barriers to PHC access were observed, leading families to seek help in emergency and urgent services, but they faced challenges while reaching resolution to health problems due to lack of care continuity and non-accountability of the team ${ }^{(31)}$.

Considering the strategies for access, we have the models of nursing homes created to prioritize minorities in the United States $^{(20)}$, and the example of Malaysia that was extended across Asia, but the aborigines in the east region of the country had little access ${ }^{(21)}$. Partnerships between PHC services, the community and hospitals in Australia show interest and innovative experiences in improving access ${ }^{(28)}$ by creating care networks in care services to provide access to remote communities.

The formulation of lists with priority and essential PHC service was also one way adopted by Australian administrators to provide access and financial support to health care, particularly in rural and remote communities ${ }^{(24)}$, showing an interest in providing care to those people in geographically remote areas. Also important was the appreciation of the user's perspective in the construction of more suitable instruments for $\mathrm{PHC}^{(26)}$.

The issues related to professional training for $\mathrm{PHC}$ require a restructured way of teaching, as well as the provision and orderly allocation of professionals across the country, ensuring health care access, continuity and coverage. The need to train professionals for PHC is addressed ${ }^{(23,29)}$. For this reason, in places with shortage of doctors and nurses, training is provided to community members to ensure basic care, under the supervision of nurses ${ }^{(30)}$.

The studies show a trend to prioritize investments in PHC actions and services and the adhesion to the family medicine project, improving the geographical and financial access to health. Well-trained health professionals can ensure the fundamental right to quality primary care for everyone ${ }^{(27)}$. One study identified and analyzed the role of nurses in PHC in the British health care system by addressing their contributions to the quality of services provided, highlighting their roles as a member of the health care team, and in patient opinions, it provided improved access to services, with longer appointments, more efficient communication, and improved adherence to treatment ${ }^{(32)}$.

\section{Study limitations}

The study limitation refers to few publications that address the guarantee of care longitudinality, so this approach was not deeply discussed in this review; then further studies are required on the theme.

\section{Contributions to Nursing, health or public policy fields}

The contributions of this study to nursing and other health professionals are based on the appreciation of PHC professionals as a means to implement and expand the access, which is essential for care longitudinality and link of the community with the health teams. The strategies implemented in the various countries may support public policies to improve access in various $\mathrm{PHC}$ contexts.

\section{CONCLUSION}

In some places, specific populations such as settlers, quilombolas, immigrants, and others have particular health care strategies by their own means. Other vulnerable populations, because they need government support, have difficult access to health services. They have problems to access basic public services and, when available, they face poor service quality; however, social networks, family members, communities and traditional and alternative habits are used in several situations to fulfill or mitigate health needs.

In primary care, health workforce strengthening and professionals training are also addressed and emphasized in this review, which are essential worldwide today, as well as the awareness of professionals in terms of respecting and properly incorporating alternative, traditional, integrative and complementary therapies used by communities. The use of health care indicators is also important to improve and qualify $\mathrm{PHC}$ and then strengthen the work process of professionals.

With better qualified and strategically allocated professionals in the countries and regions, the chances of ensuring care will be greater, especially to geographically, socioeconomically or culturally vulnerable communities. Emphasis is placed on the required presence of well-trained health professionals with continued education and supervision specifically for primary care to ensure quality, care continuity, and access to services and comprehensive care.

\section{REFERENCES}

1. Brasil. Ministério da Saúde. As Cartas da Promoção da Saúde. Brasília: Ministério da Saúde; 56p. 2002.

2. Gibson O, Lisy K, Davy C, Aromataris E, Kite E, Lockwood C, et al. Enablers and barriers to the implementation of primary health care interventions for Indigenous people with chronic diseases: a systematic review. Implement Sci[Internet]. 2015[cited 2017 May 18];2;1-11. Available from: https://www.ncbi.nlm.nih.gov/pmc/articles/PMC4465476/pdf/13012_2015_Article_261.pdf

3. Souza ECF, Vilar RLA, Rocha NSPD, Uchoa AC, Rocha PM. Primary health care access and receptivity to users: an analysis of perceptions by users and health professionals. Cad Saúde Pública[Internet]. 2008[cited 2017 May 18];100-10. Available from: http://www.scielo.br/pdf/csp/v24s1/15.pdf

4. Oliveira MAC, Pereira IC. Primary Health Care essential attributes and the Family Health Strategy. Rev Bras Enferm[Internet]. 2013[cited 2017 May 23];66(Esp):158-64. Available from: http://www.scielo.br/pdf/reben/v66nspe/v66nspea20.pdf

5. Travassos C, Martins M. A review of concepts in health services access and utilization. Cad Saúde Pública[Internet]. 2004[cited 
2016 Sep 12];20:190-98. Available from: http://www.scielo.br/pdf/csp/v20s2/14.pdf

6. Mendes EV. O cuidado das condições crônicas na atenção primária à saúde: o imperativo da consolidação da estratégia da saúde da família. OPAS[Internet]. 2012[cited 2016 Sep 12];512p. Available from: http://bvsms.saude.gov.br/bvs/publicacoes/cuidado_ condicoes_atencao_primaria_saude.pdf

7. Polluste K, Kasiulevicius V, Veide S, Kringos DS, Boerma W, Lember M. Primary care in Baltic Countries: a comparison of progress and present systems. Health Policy[Internet]. 2013[cited 2016 Sep 12];109(2):122-30. Available from: https://www.ncbi.nlm.nih. gov/pubmed/22964369

8. Mendes KDS, Silveira RCCP, Galvão CM. Integrative literature review: a research method to incorporate evidence in health care and nursing. Texto Contexto Enferm[Internet]. 2008[cited 2016 Sep 12];17(4):758-64. Available from: http://www.scielo.br/pdf/ tce/v17n4/18.pdf

9. Whittemore R, Knalf K. The integrative review: update methodology. J Adv Nurs[Internet]. 2005[cited 2016 Jul 15];52(5):546-53. Available from: https://www.ncbi.nlm.nih.gov/pubmed/16268861

10. Vargas BA, Fang H, Garza J, Carter-Pokras O, Wallace SP, Rizzo JA, et al. Variations in healthcare access and utilization among Mexican immigrants: the role of documentation status. J Immigr Minor Health [Internet]. 2012[cited 2016 Sep 12];14(1):146-55. Available from: https://www.ncbi.nlm.ni h.gov/pmc/articles/PMC3256312/pdf/10903_2010_Article_9406.pdf

11. Santos JCB, Hennington EA. Nobody gives orders here: the meanings of work and health for settlers from the Landless Rural Workers' Movement. Cad Saúde Pública[Internet]. 2013[cited 2016 Sep 12];29(8):1595-604.Available from: http://www.scielo. $\mathrm{br} / \mathrm{pdf} / \mathrm{csp} / \mathrm{v} 29 \mathrm{n} 8 / \mathrm{v} 29 \mathrm{n} 8 \mathrm{a} 12 . \mathrm{pdf}$

12. Moss JA. Discovering the healthcare beliefs and practices of rural mestizo Ecuadorians: an ethnonursing study. Invest Educ Enferm[Internet]. 2014[cited 2016 Sep 12];32(2):326-36. Available from: http://www.scielo.org.co/pdf/iee/v32n2/v32n2a15.pdf

13. Santos RC, Silva MS. Living conditions and therapeutic paths in a quilombola community in Goiás, Brazil. Saude Soc[Internet]. 2014[cited 2016 Sep 12];23(3):1049-63. Available from: http://www.scielo.br/pdf/sausoc/v23n3/0104-1290-sausoc-23-3-1049. pdf

14. Wunsch S, Budó MLD, Girardon-Perlini NMO, Garcia RP, Oliveira SG. Care as a commitment of all: a study in a rural settlement. Rev Gaucha Enferm[Internet]. 2014[cited 2016 Sep 12];35(4):65-71. Available from: http://www.scielo.br/pdf/rgenf/v35n4/ pt_1983-1447-rgenf-35-04-00065.pdf

15. Bond AM, White C. Massachusetts coverage expansion associated with reduction in primary care utilization among Medicare beneficiaries. Health Serv Res[Internet]. 2013[cited 2016 Sep 12];48(6):1826-39. Available from: https://www.ncbi.nlm.nih.gov/ pmc/articles/PMC3876406/pdf/hesr0048-1826.pdf

16. Dow AW, Bohannon A, Garland S, Mazmanian PE, Retchin SM. The effects of expanding primary care access for the uninsured: implications for the health care workforce under health reform. Acad Med[Internet]. 2013[cited 2016 Sep 12];88(12):1855-61. Available from: http://www3.med.unipmn.it/papers/2014/LWW/2014-01-13_lww/The_Effects_of_Expanding_Primary_Care_ Access_for.22.pdf

17. Cheng TL, Wise PH, Halfon N. Quality health care for children and the Affordable Care Act: a voltage drop checklist. Pediatrics[Internet]. 2014[cited 2016 Sep 12];134(4):794-802. Available from: http://pediatrics.aappublications.org/content/ pediatrics/134/4/794.full.pdf

18. Rhodes KV, Kenney GM, Friedman AB, Saloner B, Lawson CC, Chearo D, et al. Primary care access for new patients on the eve of health care reform. JAMA[Internet]. 2014[cited 2016 Sep 12];174(6):861-69. Available from: http://jamanetwork.com/journals/jamainternalmedicine/ fullarticle/1857092

19. Ortega AN, Rodriguez HP, Bustamante AV. Policy dilemmas in Latino health care and implementation of the Affordable Care Act. Annu Rev Public Health[Internet]. 2015 [cited 2016 Sep 12];36(18):525-44. Available from: https://www.ncbi.nlm.nih.gov/pmc/ articles/pmid/25581154/

20. Grant R, Greene D. The health care home model: primary health care meeting public health goals. Am J Public Health [Internet]. 2012[cited 2016 Sep 12];102(6):1096-103. Available from: https://www.ncbi.nlm.nih.gov/pmc/articles/PMC3483945/pdf/ AJPH.2011.300397.pdf

21. Jiwa M, Othman S, Hanafi NS, Ng CJ, Khoo EM, Chia YC. Healthcare in Asia: a perspective from primary care at the gateway to a continent. Qual Prim Care [Internet] 2012[cited 2016 Sep 12];20(5):17-20. Available from: http://primarycare.imedpub.com/ healthcare-in-asia-a-perspective-from-primary-care-at-the-gateway-to-a-continent.pdf

22. Tan L, Carr J, Reid J. New Zealand evidence for the impact of primary healthcare investment in Capital and Coast District Health Board. NZMJ[Internet]. 2012[cited 2016 Sep 12];125(1352):7-27. Available from: https://www.nzma.org.nz/journal/read-the-journal/ all-issues/2010-2019/2012/vol-125-no-1352/article-tan

23. Groenewegen PP, Jurgutis A. A future for primary care for the greek population. Qual Prim Care[Internet]. 2013 [cited 2016 Sep 12];21(6):369-78. Available from: http://primarycare.imedpub.com/a-future-for-primary-care-for-the-greek-population.pdf

24. Thomas SL, Wakerman J, Humphreys JS. What core primary health care services should be available to Australians living in rural and remote communities? BMC Fam Pract [Internet]. 2014. [cited 2016 Sep 14];143(15):1-9. Available from: https://bmcfampract. biomedcentral.com/articles/10.1186/1471-2296-15-143 
25. Bodenheimer T, Ghorob A, Willard-Grace R, Grumbach K. The 10 building blocks of high-performing primary care. Ann Fam Med[Internet]. 2014[cited 2016 Sep 14];12(2):166-71. Available from: https://www.ncbi.nlm.nih.gov/pmc/articles/PMC3948764/ pdf/0120166.pdf

26. Aguilera CCE, Brandão AL, Bocater PPM. Study on evaluation of dimensions of the Family Health Strategy in the user's perspective. Physis[Internet] 2014[cited 2016 Sep 14];24(1):127-46. Available from: http://www.scielo.br/pdf/physis/v24n1/0103-7331physis-24-01-00127.pdf

27. Esmaeili R, Hadian M, Rashidian A, Shariati M, Ghaderi H. Family Medicine in Iran: Facing the Health System Challenges. Glob J Health Sci[Internet] 2015[cited 2016 Sep 12];7(3):260-6. Available from: http://www.ccsenet.org/journal/index.php/gjhs/article/ view/40702/23471

28. Reeve C, Humphreys J, Wakerman J, Carter M, Carroll V, Reeve D. Strengthening primary health care: achieving health gains in remote region of Australia. Med J Aust[Internet]. 2015[cited 2016 Sep 15];202(9):483-7. Available from: https://www.mja.com. au/system/files/issues/202_09/ree00894.pdf

29. Takamura A. The present circumstance of primary care in Japan. Qual Prim Care[Internet]. 2015[cited 2017 Feb 12];23(5):262-6. Available from: http://primarycare.imedpub.com/the-present-circumstance-of-primary-care-injapan.pdf

30. Laryea S, Goede H, Barten F. Moving toward universal health coverage: a review of comprehensive primary health care in Suriname. Rev Panam Salud Publica[Internet] 2015[cited 2017 Feb 20];37(6):415-21. Available from: http://www.scielosp.org/ pdf/rpsp/v37n6/v37n6a07.pdf

31. Silva RMM, Viera CS. Access to child's health care in primary care services. Rev Bras Enferm [Internet]. 2014 [cited 2017 Feb 12];67(5):794-802. Available from: http://www.scielo.br/pdf/reben/v67n5/0034-7167-reben-67-05-0794.pdf

32. Toso BRGO, Filippon J, Giovanella L. Nurses' performance on primary care in the National Health Service in England. Rev Bras Enferm [Internet]. 2016[cited 2017 Feb 12];69(1):169-77. Available from: http://www.scielo.br/pdf/reben/v69n1/en_0034-7167reben-69-01-0182.pdf 